\section{Drought Stress Increases Densities but Not Populations of Two-spotted Spider Mite on Buddleia davidii 'Pink Delight'}

\author{
Jeffrey H. Gillman', Mark W. Rieger ${ }^{2}$, and Michael A. Dirr ${ }^{3}$ \\ Department of Horticulture, The University of Georgia, Athens, GA 30602 \\ S. Kristine Braman ${ }^{2}$ \\ Department of Entomology, Georgia Experiment Station, Griffin, GA 30223
}

Additional index words. butterfly bush, tolerance, pest resistance, Tetranychus urticae, water deficit

\begin{abstract}
Two experiments were conducted to determine the effect of drought stress on the susceptibility of Buddleia davidii Franch. 'Pink Delight' to the two-spotted spider mite (Tetranychus urticae Koch). In the first experiment, drought stress was imposed by withholding water until predawn xylem pressure potential fell below -1 MPa. Shoot growth was $75 \%$ less in drought-stressed than in nonstressed plants. Mite population densities were not affected, but noninfested leaf area was $14 \%$ higher, and degree of mite damage was lower, in nonstressed plants. Evidently, the greater amount of new growth in nonstressed plants leads to lower spider mite densities by diluting populations. In a second experiment, nonstressed $B$. davidii 'Pink Delight' plants were watered every 1 to 2 days and drought-stressed plants were watered every 3 days. Spider mite populations were monitored by sampling newly expanded and mature foliage. Mite populations on mature foliage were not affected by stress, but stressed plants grew less and had larger spider mite populations on their newly expanded foliage than did nonstressed plants.
\end{abstract}

Buddleia davidii, butterfly bush, is a popular ornamental shrub grown in nurseries and gardens throughout the United States. The most significant debilitating pest of $B$. davidii is the two-spotted spider mite (Maunder, 1987). Spider mites cause aesthetic damage and increase production costs because of the need for miticide applications. Cultural factors such as temperature (Boudreaux, 1958), nutritional stress (Mellors and Propts, 1983), and drought stress affect two-spotted spider mite populations.

Conflicting results regarding the effects of drought stress on populations of two-spotted spider mite and related species in horticultural crops have been reported (Klubertanz et al., 1990; Smitley and Peterson, 1991). Many studies, primarily on agronomic crops, have indicated an increase in spider mite populations associated with an increase in drought stress (Hollingsworth and Berry, 1982; Kattes and Teetes, 1978; Smitley and Peterson, 1991; van de Vrie et al., 1972; Youngman and Barnes, 1986). Other studies, however, have indicated that mite populations decrease with increasing drought stress (Gould, 1978; Mellors et al.,

Received for publication 13 Apr. 1998. Accepted for publication 25 Aug. 1998. The cost of publishing this paper was defrayed in part by the payment of page charges. Under postal regulations, this paper therefore must be hereby marked advertisement solely to indicate this fact.

${ }^{1}$ Current address: Assistant Professor, Dept. of Horticultural Science, Univ. of Minnesota, St. Paul, MN 55108.

${ }^{2}$ Associate Professor.

${ }^{3}$ Professor.
1984; Specht, 1965). In some research, no difference was found between spider mite populations on drought-stressed and nonstressed plants (Ferree and Hall, 1980; Hare et al., 1989; Mellors and Propts, 1983; Smitley and Peterson, 1991). English-Loeb (1990) suggested that a drought stress level exists at which mites will perform best and that stress above or below this level reduces mite performance.

Drought stress negatively affects many plant functions, the most significant of which is plant growth (Hsiao et al., 1973). This reduces the area available for spider mites to infest. Drought stress may increase the suitability of a plant as a nutritional source (White, 1984) as well as reduce the plant's defensive ability (English-Loeb, 1990; Rhoades, 1979, 1983). Higher nutritional value of nonstressed plants has, however, also been reported to be beneficial to growth and development of the two-spotted spider mite (Wrensch and Young, 1975).

No consensus exists as to the effect of drought stress on population growth of twospotted spider mite. Each plant species must be evaluated separately when studying the effect of drought stress on this pest. This study examined the effects of water stress on infestations of two-spotted spider mite on Buddleia davidii 'Pink Delight'.

\section{Materials and Methods}

Expt. 1, 1996. Twenty Buddleia davidii 'Pink Delight' plants were propagated and grown in 11.3-L (3 gal) containers under greenhouse conditions at Athens, Ga., from Jan. to
June 1996. Plants were grown in $100 \%$ pine bark and topdressed with Nutricote Total 17$7-8$ (17N-3.0P-6.7K plus micronutrients) (PlantCo, Brampton, Ont., Canada). Plants were arranged in a completely randomized design on a greenhouse bench; 10 were droughtstressed and 10 were not. Water was added to plastic trays placed under each container. One liter of water was supplied to nonstressed plants every $2 \mathrm{~d}$, and soluble fertilizer [200 $\mathrm{mg} \cdot \mathrm{L}^{-1} \mathrm{~N}$ as $\left.20-10-20(20 \mathrm{~N}-4.0 \mathrm{P}-17 \mathrm{~K})\right]$ (Scotts-Sierra Horticultural Products Co., Marysville, Ohio) was added to the water every $4 \mathrm{~d}$. Predawn xylem pressure potentials of all plants were monitored every $3 \mathrm{~d}$ using a pressure chamber (Scholander et al., 1965). Drought-stressed plants were watered individually when their xylem pressure potential fell below $-1 \mathrm{MPa}$, the point at which slight wilting occurs. Watering was alternated with fertilizer solution as with nonstressed plants. Effects of water stress on growth were assessed by measuring shoot length of two young shoots from each plant over the course of the experiment.

Treatments began 26 June. To control mites already present, all plants were treated on 14 June and 1 July with Dinocap (2,4-dinitro-6octyl-phenyl-crotonate) (Diachem, Bergamo, Italy), a contact miticide with short residual activity (Briggs, 1992). Natural two-spotted spider mite infestations, originating from other Buddlea sp. present in the greenhouse, were allowed to develop from the last miticide spray until the end of the experiment on 24 July, when plant growth, mite damage, and mite infestation were recorded.

Mite populations at the end of the experiment were determined by randomly taking five leaves from each plant and counting the number of eggs, adults, and nymphs on an area $71 \mathrm{~mm}^{2}$ located at the central, basal portion of the leaf. The percentage of noninfested leaf area was calculated by dividing the number of samples that had no spider mite stages present by the total number of samples for each plant.

At the conclusion of the experiment, mite damage symptoms were calculated for each of the 20 plants independently by five people familiar with the visible characteristics of spider mite feeding. These individuals were asked to mark a tag $10 \mathrm{~cm}$ long, without gradients, at a point where they judged visible two-spotted spider mite damage to lie. The top of the tag indicated extreme mite damage $(=10)$ and the bottom of the tag no mite damage $(=0)$. The distance from the bottom of the tag to each mark represented an individual damage rating.

Statistical analyses of treatment differences between shoot growth, mite population variables, percentages of uninfested area, and damage ratings were performed using Student's $t$ test (SAS Institute, Cary, N.C.).

Expt. 2, 1997. To assess two-spotted spider mite foliar infestations on drought-stressed plants in a production setting, and to corroborate results from Expt. 1, 20 B. davidii 'Pink Delight' plants were grown in 11.3-L (3 gal) containers, outdoors at Athens, Ga., from March until the initiation of treatment. On 10 July all plants were stripped of their foliage, 
Table 1. Total shoot growth, two-spotted spider mite populations, noninfested leaf area, and damage ratings in drought-stressed and nonstressed Buddleia davidii 'Pink Delight' (Expt. 1).

\begin{tabular}{lcccccc}
\hline & & \multicolumn{3}{c}{$\begin{array}{c}\text { Mite population } \\
\left(\text { mean no./71 } \mathrm{mm}^{2}\right)\end{array}$} & \% Noninfested & Damage rating \\
\cline { 3 - 6 } Treatment & growth $(\mathrm{cm})$ & Eggs & Nymphs & Adults & leaf area & $(0-10)$ \\
\hline Drought-stressed & $0.80 \mathrm{a}^{\mathrm{z}}$ & $15.50 \mathrm{a}$ & $3.16 \mathrm{a}$ & $0.94 \mathrm{a}$ & $2.0 \mathrm{a}$ & $6.61 \mathrm{a}$ \\
Nonstressed & $3.37 \mathrm{~b}$ & $20.94 \mathrm{a}$ & $1.86 \mathrm{a}$ & $0.98 \mathrm{a}$ & $16.0 \mathrm{~b}$ & $5.36 \mathrm{~b}$ \\
\hline
\end{tabular}

${ }^{2}$ Mean separation within columns by Student's $t$ test $(P \leq 0.05)$.

sprayed with Dinocap, and topdressed with 36 $\mathrm{g}$ Nutricote Total 17-7-8. Growing medium consisted of 90 pine bark : 10 sand (by volume), which was amended with $4.8 \mathrm{~kg} \cdot \mathrm{m}^{-3}$ dolomitic lime and $1.2 \mathrm{~kg} \cdot \mathrm{m}^{-3}$ gypsum. All containers were placed in shallow plastic trays as in Expt 1. Plants were placed in a randomized complete-block design under a rain-out shelter on a gravel pad. Ten plants were subjected to drought stress and 10 plants were not. Drought-stressed plants were watered with 1 L of tapwater applied to the top of the container every $3 \mathrm{~d}$. Nonstressed plants were watered in the same manner as drought-stressed plants whenever the level of water in the shallow trays fell below the drainage holes at the base of the container. Drought stress was monitored weekly by measuring shoot length as in Expt. 1, and by measuring predawn xylem pressure potential from one fully expanded, healthy leaf per plant once a week immediately before watering. Mite populations on new growth were determined by sampling five leaves from the first fully expanded leaf pairs and counting the number of eggs and motile stages as described for Expt. 1. Mite populations originated from other Buddleia sp. present in the area. Populations were sampled weekly from 5 until 26 Aug. Mite populations on old growth were determined at the conclusion of the experiment using the same procedure as that used for sampling new growth, except that only leaves on the third, fully expanded leaf pair were sampled.

Data were analyzed as described for Expt. 1.

\section{Results and Discussion}

Expt. 1, 1996. Shoot growth of nonstressed plants was significantly greater than that of drought-stressed plants (Table 1). Drought stress caused slight wilting between irrigations. Leaves of severely drought-stressed plants abscised toward the end of the experiment because of extreme water stress and mite infestation. Drought-stressed plants probably received less fertilizer than nonstressed plants, but neither treatment should have been defi- cient in any nutrient, given the high rate of fertilizer applied.

Expanding foliage appeared to be less infested with spider mites than was mature foliage across both treatments. Percentage of noninfested area was significantly less and mite damage, as assessed by survey, was significantly greater in drought-stressed plants than in nonstressed plants. Numbers of adults, nymphs, and eggs did not differ statistically between treatments (Table 1).

The lack of significant differences in mite populations between drought-stressed and nonstressed plants is consistent with data reported by other researchers (Ferree and Hall, 1980; Hare et al., 1989; Mellors and Propts, 1983; Smitley and Peterson, 1991; Wrensch and Young, 1975). This indicates that similar populations of two-spotted spider mites develop on drought-stressed and nonstressed $B$. davidii. Spider mites feed on the older leaves of infested plants and disperse to new leaves as the old leaves become resource-deficient (Wrench and Young, 1975). If, due to some environmental factor, no new growth develops, the plant will not be able to outgrow an exploding mite population (Smith, 1989). This results in a higher percentage of damage per unit leaf surface area on a drought-stressed than on a nonstressed plant, even though populations are similar. This is corroborated by greater noninfested area in nonstressed plants.
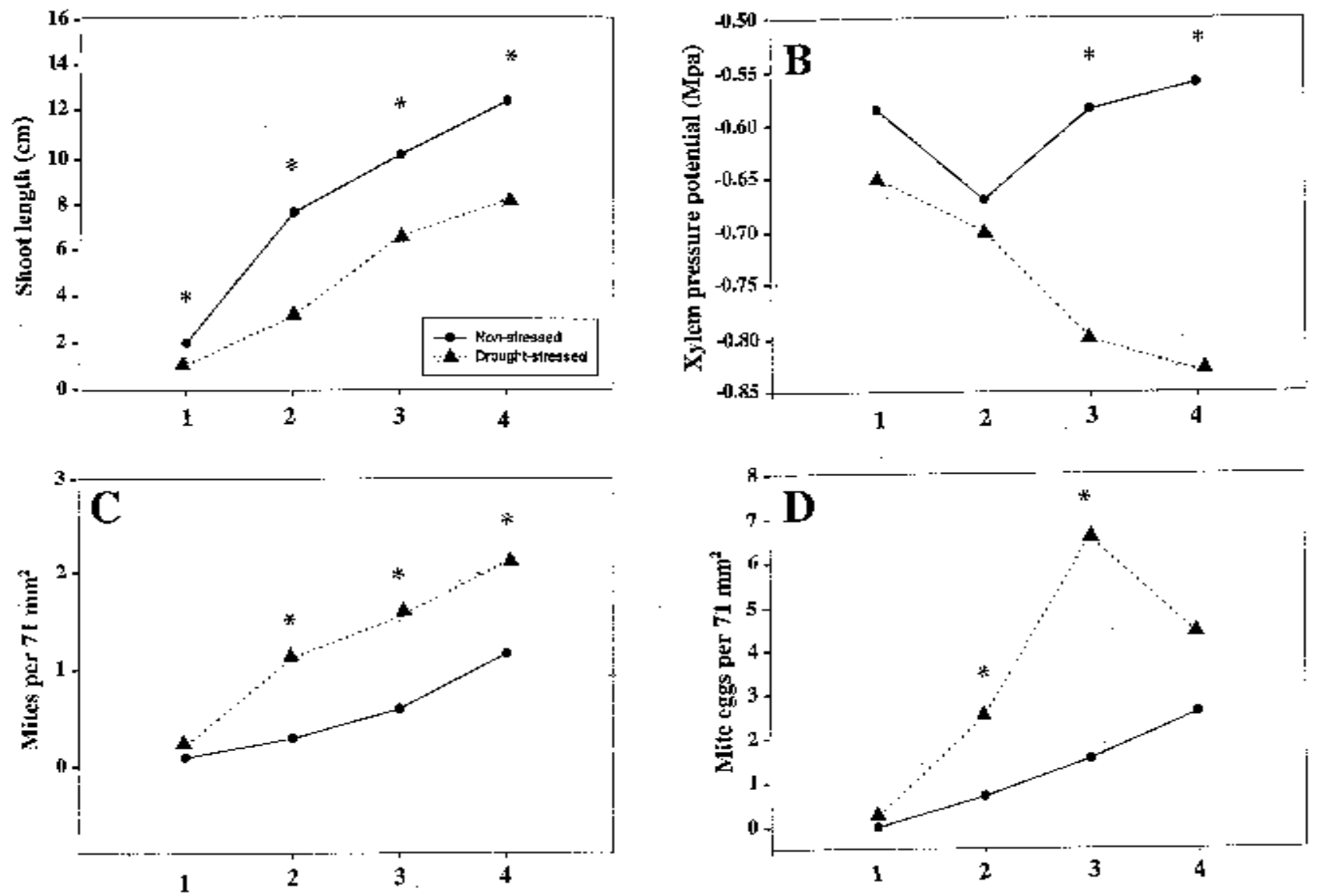

Fig. 1. Effects of drought stress on Buddleia davidii 'Pink Delight' (Expt. 2). (A) Shoot length; (B) xylem pressure potential; (C) number of motile mite stages on newly expanded foliage; and (D) number of mite eggs on newly expanded foliage. Asterisks indicate significant $(P \leq 0.05)$ differences between means within each date. 
Table 2. Two-spotted spider mite populations on the third, fully expanded leaf pair in drought-stressed and nonstressed Buddleia davidii 'Pink Delight' (Expt. 2).

\begin{tabular}{lccc}
\hline \hline & \multicolumn{3}{c}{ Mean no. per 71 $\mathrm{mm}^{2}$} \\
\cline { 2 - 4 } Treatment & Eggs & Nymphs & Adults \\
\hline Drought-stressed & $5.65 \mathrm{a}^{\mathrm{z}}$ & $0.80 \mathrm{a}$ & $0.84 \mathrm{a}$ \\
Nonstressed & $5.18 \mathrm{a}$ & $0.69 \mathrm{a}$ & $0.86 \mathrm{a}$ \\
\hline
\end{tabular}

${ }^{2}$ Mean separation within columns by Student's $t$ test $(P \leq 0.05)$

Expt. 2, 1997. None of the plants in either treatment showed visible signs of water stress, such as wilted leaves, during the experiment. Plants produced sufficient foliage to test xylem pressure potential on 7 Aug. Shoots of drought-stressed plants grew significantly less over the course of the experiment (Fig. 1A), and had lower xylem pressure potentials before watering during the last 2 weeks of the experiment, than did nonstressed plants (Fig. 1B).

Similar populations of eggs, nymphs, and adults were present on old growth of droughtstressed and nonstressed plants at the conclusion of the experiment (Table 2). Weekly sampling of new growth showed significantly more motile mites (Fig. 1C) on drought-stressed than on nonstressed plants for 3 of the 4 weeks of sampling, and significantly more mite eggs for 2 of the 4 weeks (Fig. 1D).

The fact that spider mite populations on Buddleia are less concentrated on the new growth of a faster-growing plant than on a similar slower-growing plant is consistent with tolerance, which is the ability of a plant to outgrow an arthropod infestation (Smith, 1989). Tolerance is affected by environmental factors, including temperature (Schweissing and Wilde, 1978) and nutritional status (Schweissing and Wilde, 1979), which can affect the growth and development of both pest and host (Smith, 1989).

With regard to $B$. davidii, the perception that mites reach damaging levels more quickly on drought-stressed than on nonstressed plants is due to a greater plant tolerance to twospotted spider mite infestations, rather than from direct effects of drought stress on mite development. The increased growth of nonstressed plants prevents the mites from infesting expanding foliage as rapidly as they would infest the more slowly expanding foliage of a drought-stressed plant.

\section{Literature Cited}

Boudreaux, H.B. 1958. The effect of relative humidity on egg-laying, hatching, and survival in various spider mites. J. Insect Physiol. 2:65-72.

Briggs, S.A. 1992. Basic guide to pesticides. Hemisphere, Philadelphia.

English-Loeb, G.M. 1990. Plant drought stress and outbreaks of spider mites: A field test. Ecology 71:1401-1411.

Ferree, D.C. and F.R. Hall. 1980. Effects of soil water stress and two spotted spider mites on net photosynthesis and transpiration of apple leaves. Photosyn. Res. 1:189-197.

Gould, F. 1978. Resistance of cucumber varieties to Tetranychus urticae: Genetic and environmental determinants. J. Econ. Entomol. 71:680-683.

Hare, J.D., J.E. Pherson, T. Clemens, and R.R. Youngman. 1989. Combined effects of differential irrigation and feeding injury by the citrus red mite (Acari: Tetranychidae) on gas exchange of orange leaves. J. Econ. Entomol. 82:204 208.

Hollingsworth, C.S. and R.E. Berry. 1982. Two spotted spider mite (Acari: Tetranychidae) in peppermint: Population dynamics and influence of cultural practices. Environ. Entomol. 11:1280 1284.

Hsiao, T.C., E. Acevedo, E. Fereres, and D.W. Henderson. 1976. Stress metabolism. Water stress, growth, and osmotic adjustment. Philos. Trans. Royal Soc. London, B273:479-500.

Kattes, D.H. and G.L. Teetes. 1978. Selected factors influencing the abundance of banks grass mite in sorghum. Texas Agr. Expt. Sta. Bul. 1186.

Klubertanz, T.H., L.P. Pedigo, and R.E. Carlson. 1990. Effects of plant moisture stress and rainfall on population dynamics of the two-spotted spider mite (Acari: Tetranychidae). Environ. Entomol. 19:1773-1779.

Maunder, M. 1987. Notes on tender species of Buddleia. The Plantsman 9:64-80.

Mellors, W.K., A. Allegro, and A.N. Hsu. 1984. Effect of carbofuran and water stress on growth of soybean plants and two spotted spider mite (Acari: Tetranychidae) populations under greenhouse conditions. Environ. Entomol. 13:561567.
Mellors, W.K. and S.E. Propts. 1983. Effects of fertilizer level, fertility balance, and soil moisture on the interaction of two-spotted spider mites (Acarina: Tetranychidae) with radish plants. Environ. Entomol. 12:1239-1244.

Rhoades, D.F. 1979. Evolution of plant chemical defense against herbivores, p. 3-54. In: G.A Rosenthal and D.H. Janzen (eds.). Herbivores: Their interaction with secondary metabolites. Academic, New York.

Rhoades, D.F. 1983. Herbivore population dynamics and plant chemistry, p. 155-200. In: R.F. Denno and M.S. McClure (eds.). Variable plants and herbivores in natural and managed systems. Academic, New York.

Scholander, P.F., H.T. Hammel, D. Edda, D. Bradstreet, and E.A. Hemmingsen. 1965. Sap pressure in vascular plants. Science 148:339-346.

Schweissing, F.C. and G. Wilde. 1978. Temperature influence on greenbug resistance of crops in the seedling stage. Environ. Entomol. 7:831-834.

Schweissing, F.C. and G. Wilde. 1979. Temperature and plant nutrient effects on resistance of seedling sorghum to the greenbug. J. Econ. Entomol. 72:20-23.

Smith, C.M. 1989. Plant resistance to insects: A fundamental approach. Wiley, New York.

Smitley, D.R. and N.C. Peterson. 1991. Two spotted spider mite (Acari: Tetranychidae) population dynamics and growth of Euonymus alata 'Compacta' in response to irrigation rate. J. Econ. Entomol. 84:1806-1811.

Specht, H.B. 1965. Effects of water stress on the reproduction of European red mite, Panonychus ulmi (Koch) on young apple trees. Can. Entomol. 97:82-85.

Van de Vrie, M., J.A. McMurtry, and C.B. Huffaker. 1972. Ecology of tetranychid mites and their natural enemies: A review. III. Biology, ecology, and pest status and host-plant relations of tetranychids. Hilgardia 41:343-432.

White, T.C.R. 1984. The abundance of invertibrate herbivores in relation to the availability of nitrogen in stressed food plants. Oecologia 63:90-105.

Wrensch, D.L. and S.S.Y. Young. 1975. Effects of quality of resource and fertilization status on some fitness traits of the two-spotted spider mite, Tetranychus urticae Koch. Oecologia 18:259-267.

Youngman, R.R. and M.M. Barnes. 1986. Interaction of spider mites (Acari: Tetranychidae) and water stress on gas-exchange rates and water potential of almond leaves. Environ. Entomol. $15: 594-600$ 